\title{
Detection and functional characterisation of the transcription factor peroxisome proliferator-activated receptor $\gamma$ in lutein cells
}

\author{
B Löhrke, T Viergutz, S K Shahi, R Pöhland, K Wollenhaupt, \\ T Goldammer, H Walzel ${ }^{1}$ and $\mathbf{W}$ Kanitz
}

Research Institute of Animal Biology Dummerstorf-Rostock, Wilhelm-Stahl-Allee 2, D-18196 Dummerstorf, Germany and ${ }^{1}$ Faculty of Medicine, University of Rostock, Rostock, Germany

(Requests for offprints should be addressed to B Löhrke, Forschungsinstitut für die Biologie landwirtschaftlicher Nutztiere, Wilhelm-Stahl-Allee 2, 18196 Dummerstorf, Germany)

\begin{abstract}
A prominent functional change during differentiation of lutein cells from follicular thecal and granulosa cells is an enhanced production and secretion of progestins. The regulation of this process is not fully understood but may be associated with the expression of transcription factors which activate genes, products of which are involved in pathways of the cholesterol and lipid metabolism. As peroxisome proliferator-activated receptors (PPARs) play a role in both pathways, we were interested in the expression of PPAR $\gamma$, a PPAR form which is involved in adipogenic differentiation. First, we were able to show the expression of PPAR $\gamma$ in bovine lutein cells (day 12 of the ovarian cycle) at the mRNA and protein level by imaging, flow cytometry and blot analysis, and secondly a role of PPAR $\gamma$ in the secretion of progesterone. The cells $(24 \mathrm{~h}$ culture) responded dose dependently by increasing progesterone secretion (up to $1 \cdot 5$-fold of the basal level) to an
\end{abstract}

endogenous ligand of PPAR $\gamma, 15-$ deoxy- $\Delta^{12,14}$ prostaglandin $\mathrm{J}_{2}\left(15-\mathrm{dPGJ}_{2}\right)$ and to the thiazolidinedione ciglitizone. Aurintricarboxylic acid (ATA) was found to reduce the intracellular PPAR $\gamma$ level and to promote cell cycle progress, indicating that ATA can be used as a tool for experimental changes of PPAR $\gamma$ proteins in intact cells and for studying the physiological consequences. The ATA-mediated decrease of PPAR $\gamma$ was accompanied by reduced progesterone production and a progression of the cell cycle, suggesting a function of PPAR $\gamma$ in both processes. The response to ATA was abrogated by a high dose $(>490 \mathrm{nM})$ of $15-\mathrm{dPGJ}_{2}$, suggesting that $15-\mathrm{dPGJ}_{2}$ exerts its effect on steroidogenic activity via PPAR $\gamma$ and that the $15-\mathrm{dPGJ}_{2}-\mathrm{PPAR} \gamma$ system plays a role in the maintenance of a differentiated quiescent stage in lutein cells.

Journal of Endocrinology (1998) 159, 429-439

\section{Introduction}

Lutein cells develop from follicular-theca and granulosa cells into small and large cells which lose their proliferative activity, stop oestrogen production (Monniaux et al. 1994) and enhance their steroidogenic activity for progestin secretion (Goldring et al. 1986, Doody et al. 1990). The altered function is accompanied by a change in the expression of enzymes involved in steroidogenic activity (Doody et al. 1990). This implies regulatory events at the transcriptional level. However, the underlying mechanism is not known.

Peroxisome proliferator-activated receptors (PPARs) are transcription factors and part of the nuclear receptor superfamily that includes receptors for steroids, thyroid hormones and retinoids (Issemann \& Green 1990, Schmidt et al. 1992). The PPARs act by binding to specific sequences (hormone response elements) in the promoter region of the target genes (Gulick et al. 1994, Schoonjans et al. 1995). The receptors are inactive in the absence of their activating hormone ligand and in the absence of retinoid receptors (RXR). The transcription is activated subsequent to heterodimerisation of PPAR and RXR. This occurs after binding of the respective ligands by the ligand-binding domains (Keller et al. 1993). In the case of PPAR $\gamma, 15$-deoxy- $\Delta^{12,14}$ prostaglandin $\mathrm{J}_{2}\left(15-\mathrm{dPGJ}_{2}\right)$ is the natural ligand and 9-cis retinoic acid is the ligand for RXR (Forman et al. 1995, Kliewer et al. 1995). The prostaglandin is intracellularly synthesised via the arachidonic acid- $\mathrm{PGD}_{2}-\mathrm{PGJ}_{2}$ pathway (Fukushima 1992). This pathway is regulated by the rate-limiting enzymes of the group $A_{2}$ phospholipases (Dennis 1994) which are active in corpora lutea (Sawada \& Carlson 1991).

Together with another group of transcription factors, the sterol receptor element binding proteins (SREBP), which have been shown to regulate intracellular cholesterol homeostasis (Brown \& Goldstein 1997), PPARs mediate the induction of some genes which encode mitochondrial rate-limiting enzymes of cholesterol and 
fatty acid metabolism (Gulick et al. 1994, Rodriguez et al. 1994), a prerequisite for the PPARs' role in the regulation of cellular steroidogenic activity. More recently the expression of the PPAR $\alpha$ form of the PPARs was demonstrated at mRNA level in the corpus luteum (Nunez et al. 1997) and PPAR $\gamma$ mRNA was detected in bovine lutein cells (Sundvold et al. 1997), whereas information about the expression at the protein level and the function of PPAR $\gamma$ in lutein cells is apparently lacking. We demonstrate here the expression of PPAR $\gamma$ in bovine midphase lutein cells at mRNA and protein level, and the involvement of $\operatorname{PPAR} \gamma$ in regulation of progesterone secretion and in the maintenance of a quiescent differentiated stage of lutein cells.

\section{Materials and Methods}

\section{Chemicals and biochemicals}

PPAR $\gamma$ antibodies and $15-\mathrm{dPGJ}_{2}$ were obtained from Cayman-Alexis (Grünberg, Germany), the thiazolidinedione (ciglitizone) from Biomol (Hamburg, Germany) and the anti-phosphotyrosine antibodies from BoehringerMannheim (Mannheim, Germany). All other chemicals, hormones, and antibodies were from Sigma Chemical Co. (Deisenhofen, Germany) where not otherwise stated.

\section{Cells}

The study was focused on day 12 lutein cells, as in the midphase cycle the progesterone secretion remains high, indicative of intact cell function. Despite functional integrity, morphological changes occur, including accumulation of lipid droplets (Fields et al. 1992) indicative of metabolic changes thought to be regulated by PPAR $\gamma$ in other cell systems (Keller et al. 1993, Kliewer et al. 1995). However, to compare the levels of expression, some experiments were also carried out using day 5 lutein cells. Corpora lutea were obtained by ovariectomy, which was performed on day 5 and 12 (three animals in each case) of the oestrous cycle (oestrous=day 0 ) in epiduraland locally anaesthetised cows in accordance with the German Federal Law for Care of Animals. The corpora lutea were surgically removed. The tissue was placed on gauze $(60 \mu \mathrm{m}$ pores), minced, and gently ground with a glass rod, covering the tissue with Ham F12 medium buffered with Hepes (25 mM, pH 7.4) and containing $2 \mathrm{mM}$ EDTA to facilitate cell dissociation. The cell suspension was filtered, the cells spun off $(200 \mathrm{~g}, 10 \mathrm{~min})$, and erythrocytes lysed by resuspending the cells in water. Lysis was stopped after $10 \mathrm{~s}$ by adding concentrated saline to achieve $0.85 \%$ saline. After centrifugation the cells were resuspended in serum-free, EDTA-free, Hepes-buffered Ham F12 with $10 \mathrm{ng} / \mathrm{ml}$ insulin (culture medium). Cell density was determined by a cell counter (Coulter, Krefeld, Germany), cell viability by exclusion of trypan blue or $40 \mu \mathrm{M}$ propidium iodide (PI). PI uptake was checked by flow cytometry; the viability was $>95 \%$. Aliquots $\left(10^{6}\right.$ cells $\left./ \mathrm{ml}\right)$ were plated in 24-well and 96-well culture plates (Greiner, Frinckenhausen, Germany) without and with additives as indicated in Results. Granulosa cells from follicles $5 \pm 1 \mathrm{~mm}$ in diameter (two ovaries from two animals) were checked for the expression of PPAR $\gamma$ in order to gather some information about the specificity of $\operatorname{PPAR} \gamma$ expression. The cells were obtained by aspiration of the follicle as previously described (Tiemann et al. 1993). Then they were fixed and immunostained as described for lutein cells.

\section{Progesterone assay}

Progesterone concentrations (in culture medium or in serum to check the oestrous cycle) were measured in a direct RIA. Dilution curves of the samples were parallel to the standard curve. The intra- and interassay coefficients of variation were 8 and $11 \%$. The detection limit was $15 \mathrm{pg} / \mathrm{ml}$. Progesterone from lutein cells was expressed as the amount of hormone secreted by $10^{6}$ viable cells per $24 \mathrm{~h}$.

\section{Luteinising hormone $(\mathrm{LH})$ receptor detection}

To explore the level of PPAR $\gamma$-mediated steroidogenic regulation by PPAR $\gamma$ ligands, the expression of $\mathrm{LH}$ receptors, a prerequisite for CAMP-mediated regulation of the steroidogenesis in lutein cells, was measured. Ovine LH (2.5 IU/mg, Sigma) was fluoresceinated with a commercial kit (Sigma). The procedure followed the recommendations of the manufacturer with the modification that the buffer for fluorescein isothiocyanate (FITC) conjugation was $50 \mathrm{mM} \mathrm{Na}$ phosphate $(\mathrm{pH} 7 \cdot 8$ ) in $200 \mathrm{mM}$ $\mathrm{NaCl}$ so that $60-70 \%$ of the biological activity of $\mathrm{LH}$ was maintained after fluoresceination (about 2 molecules FITC/molecule LH). Day 12 cells were incubated with FITC-LH $\left(2-20 \mu \mathrm{g} / 10^{5}\right.$ cells per $\mathrm{ml}$ PBS, $\mathrm{pH} 7 \cdot 3$, with $2 \mathrm{mg} / \mathrm{ml}$ BSA and $\left.0 \cdot 1 \% \mathrm{NaN}_{3}\right)$. FITC-LH binding was saturable and displaced (65-73\%) by unlabelled LH (200-fold excess) in cells size-gated by flow cytometry.

\section{Phenotyping}

Large lutein cells were identified by flow cytometry (Coulter, Elite) according to size and granularity. The size was determined by measuring the time of flight on the peak forward scatter signal. The data were identical with those obtained by relating the forward scatter signals to standard beads (Coulter). The latter approach was routinely used. The bulk of the large, size-gated cells $(16 \pm 4 \mu \mathrm{m})$ expressed LH receptors $(59-70 \%$, the variation was due to individual differences), indicating lutein cell phenotype.

\section{Cell cycle analysis}

Cells were fixed in ethanol (70\%), washed and treated with RNAase $\left(1 \mathrm{mg} / \mathrm{ml}\right.$ in $\left.\mathrm{PBS}, 37^{\circ} \mathrm{C}, 30 \mathrm{~min}\right)$ after 
denaturation of DNases by heating $\left(85^{\circ} \mathrm{C}, 60 \mathrm{~min}\right)$ the RNAase solution (Stöhr et al. 1978). After incubation for 30 min with PI $(70 \mu \mathrm{M})$ in $5 \mathrm{mM}$ Hepes, $\mathrm{pH} 7 \cdot 3$, in $150 \mathrm{mM} \mathrm{NaCl}$, flow cytometry was performed (Coulter, Elite) and the cell cycle was analysed by a computer-aided Multicycle Program (Phoenix, San Diego, CA, USA).

\section{Western blot}

Cells were lysed by cold aqueous $0 \cdot 1 \%$ sodium citrate with $0 \cdot 1 \%$ Triton X-100; the lysate was fractionated by centrifugation $\left(1000 \mathrm{~g}, 10 \mathrm{~min}, 4^{\circ} \mathrm{C}\right.$ and $110000 \mathrm{~g}, 1 \mathrm{~h}$, $\left.4{ }^{\circ} \mathrm{C}\right)$. The supernatant of the ultracentrifugate was immediately placed on PAGE and the separated proteins were blotted onto nitrocellulose as described (Löhrke et al. 1993). PPAR $\gamma$ was detected by commercial rabbit antiPPAR $\gamma$ antibodies to the PPAR $\gamma$ amino acid sequence 284-298. Staining was developed by peroxidaseconjugated anti-rabbit $\mathrm{F}\left(\mathrm{ab}^{\prime}\right)_{2}$ and densitometry was performed as described (Löhrke et al. 1993). Phosphorylation was detected by anti-phosphotyrosine antibodies to phosphorylated tyrosine moieties of proteins according to the instructions of the manufacturer. The antibodies did not react with nucleotides, phosphoserine, phosphothreonine or phosphohistidine as tested by the manufacturer (Boehringer-Mannheim).

\section{$P P A R \gamma$ detection in cells}

Lutein cells were fixed in methanol $\left(-20^{\circ} \mathrm{C}\right)$ for $4 \mathrm{~min}$, using 1 volume lutein cell suspension $\left(10^{6}\right.$ cells $\left./ \mathrm{ml}\right)$ and 10 volumes methanol. The cells were spun off $\left(150 \mathrm{~g}, 0{ }^{\circ} \mathrm{C}\right.$, $5 \mathrm{~min}$ ), resuspended in PBS containing $0 \cdot 2 \%$ BSA ( $\mathrm{pH}$ $7 \cdot 4)$, and aliquots were plated (24-well plastic microplates). The cells were incubated $\left(2 \mathrm{~h}, 22{ }^{\circ} \mathrm{C}\right)$ with rabbit anti-PPAR $\gamma$ antibodies used at a final dilution of 1:400, and the non-bound antibodies were washed out. Next, the cells were incubated for $2 \mathrm{~h}$ at $22^{\circ} \mathrm{C}$ with phycoerythrinconjugated anti-rabbit $\mathrm{F}\left(\mathrm{ab}^{\prime}\right)_{2}$ antibody fragments (PBS, $\mathrm{pH} 7 \cdot 2,0 \cdot 2 \%$ BSA, $1 \mathrm{mM}$ EDTA). The fluorescence was quantified by flow cytometry.

\section{Flow cytometry}

Quantitative analysis of cellular fluorescence was performed by flow cytometry to analyse the cells simultaneously according to size, granularity, LH receptors, and PPAR $\gamma$ expression (portion of cells expressing PPAR $\gamma$ and PPAR $\gamma$ content per cell). The analysis was analogous to a described method (Löhrke et al. 1997). Briefly, an argon laser-equipped flow cytometer (Coulter, Elite) recording emissions of multiple fluorescence (green, orange, red) excited at $488 \mathrm{~nm}$ (counting 5000 cells) was used. Cells of interest were identified by three successive steps: (1) by establishing a histogram on the basis of cell size and granularity, (2) by establishing the fluorescence histogram, and (3) by projecting the fluorescence into the sizegranularity histogram. The cells were gated and the portion of cells and their fluorescence intensity arising from a second fluorogenic label were automatically calculated.

\section{PPAR $\gamma$ degradation}

Day 12 lutein cells $\left(10^{6} / \mathrm{ml}\right)$ were incubated without and with $10 \mu \mathrm{M}$ actinomycin $\mathrm{D}$ to block de novo synthesis of proteins and $10 \mu \mathrm{M}$ aurintricarboxylic acid (ATA) for $24 \mathrm{~h}$ in culture medium. ATA was used because preliminary experiments showed the drug to inhibit the expression of PPAR $\gamma$. After incubation, cells were fixed in methanol and immunostained as described above. Non-specific fluorescence obtained by omitting the PPAR $\gamma$-specific antibody was automatically subtracted, recording the percentage of fluorescence positive cells and the fluorescence intensity per cell. By calibrating the fluorescence intensity by standard beads (26 p, Flow Cytometry Standards Corporation, Leiden, The Netherlands) the amount of $\operatorname{PPAR} \gamma$ per cell was calculated. The assumptions for the calculation were that, according to the instructions of the manufacturer, the ratio of label to antibody was 3-4:1 (molecules:molecule) and the ratio of binding between rabbit anti-PPAR $\gamma$ and anti-rabbit $\mathrm{F}(\mathrm{ab})_{2}$ antibody was 2:1 (molecules:molecule), that the rabbit anti-PPAR $\gamma$ antibody recognises a single epitope defined by the amino acid sequence 284-298 of the PPAR $\gamma$ molecule, and that the dissociation rate of high affinity antibodies is negligible.

\section{$R N A$ and $c D N A$}

For the preparation of total RNA a commercial kit (Quiagen, Hilden, Germany) was used. Freshly prepared lutein cells were homogenised (Ultra Turrax, Staufen, Germany half-maximal speed) in the lysis buffer of the kit. The homogenate was processed according to the instructions of the manufacturer. The RNA was checked for intactness by formaldehyde-containing agarose $(1.5 \%)$ gel electrophoresis (Tontonoz et al. 1994). The mRNA$\operatorname{PPAR} \gamma$ was amplified by reverse transcription polymerase chain reaction (PCR) using a commercial kit (BoehringerMannheim). The construction of the primers $(1.2 \mathrm{~kb}$ : 5'-CAG TGT GAA TTA CAG CAA ATC TCT and 5'-AAC TTC ACA GCA AAC TCA AAC TTA; 0.76 kb: 5'-AAA ATC AAG TTC AAA CAT ATC ACC and 5' GTT TTT AAA TGC TTT TTC ACA GTA) was based on published PPAR $\gamma$ cDNA sequence (Chen et al. 1993, Zhu et al. 1993). The PCR was performed according to the conditions defined by computing the primer sequences $\left(35\right.$ cycles at $94{ }^{\circ} \mathrm{C}$ for $30 \mathrm{~s}, 56^{\circ} \mathrm{C}$ for $40 \mathrm{~s}$, and $68^{\circ} \mathrm{C}$ for $70 \mathrm{~s}$ ). The documentation and the measurement of the electrophoretic migration of the PCR products in comparison with molecular mass standards were performed by computer-aided densitometry (Herolab, Wiesloch, Germany). 

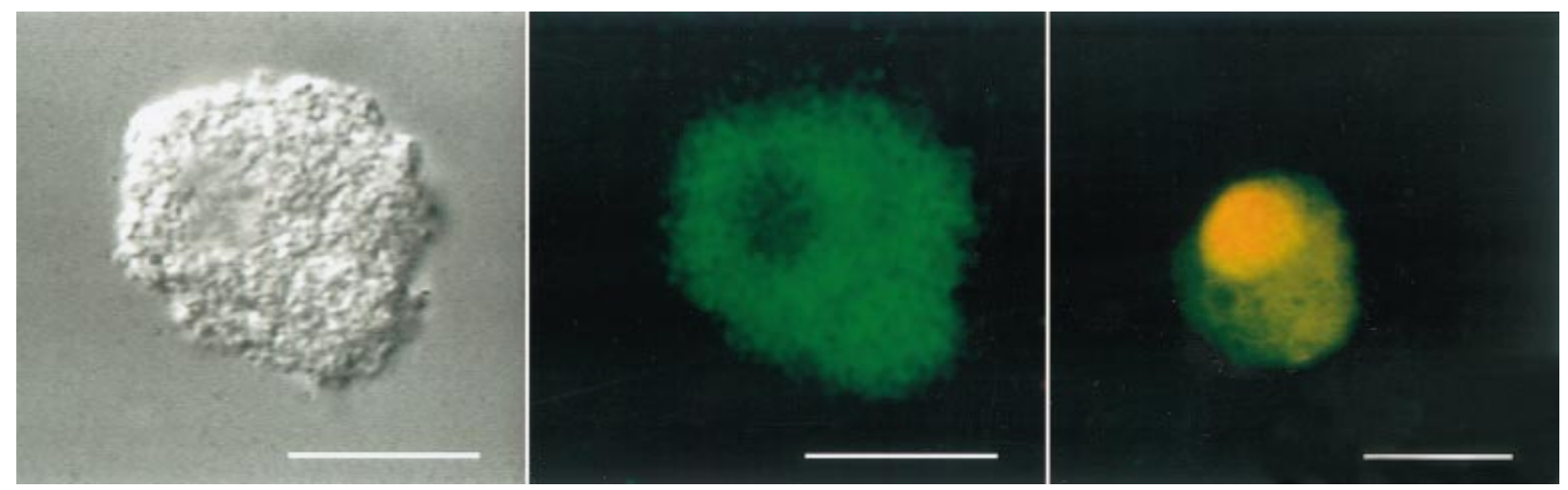

Figure 1 PPAR $\gamma$ detection in lutein cells by imaging. PPAR $\gamma$, imaged by orange stain (right panel) is predominantly located in the nucleus of lutein cells. Staining can be compared with the control (middle) and with a differential interference contrast micrograph (left) of day 12 lutein cells. Fluorescence was developed in fixed cells after treatment with rabbit antibodies to PPAR $\gamma$ and phycoerythrinconjugated anti-rabbit antibodies. The control was obtained by omitting the first antibody. Bars represent $10 \mu \mathrm{m}$.

\section{PPAR $\mathrm{\gamma}$ imaging}

Cells were fixed and immunostained as described above and spread on slides. Observations were carried out with a fluorescent microscope (Nikon, Dusseldorf, Germany) equipped with a colour video camera (Hamamatsu, Herrsching, Germany) and a computer-aided photomultiplier for fluorescence detection. Fluorescence was simultaneously excited at $360 \mathrm{~nm}$ (fluorescence of the nucleus and nucleotides of the cytoplasm) and at $480 \mathrm{~nm}$ (fluorescence of the immunostain). The emission was recorded through dichroic mirrors followed by a combination of band pass filters and cut-off filters to record the blue and green (FITC) or orange (phycoerythrin) fluorescence emissions.

\section{Statistical analysis}

Unless otherwise stated, experimental data are presented as the mean \pm s.D. of duplicate measurements of three independent experiments.

ANOVA and Tukey's comparison methods were used for comparison among means and Student's $t$-test when two means had to be compared. ANOVA followed by a least-significant difference test was used in sets of relative data subjected to arcsin transformation prior to statistical analysis. Percentage data obtained by flow cytometry were analysed by $\chi^{2}$ analysis (internal program package of the flow cytometer). All other analyses, including the analysis of linear regression, were performed by Jandel Scientific (Graz, Austria) and SAS (NC, USA) computer-aided program packages.

Significance was considered at the $P<0.05$ level under the condition that the power of the tests displayed by the Jandel program package was sufficient. Curve fitting from data points in dose dependency experiments was made by a three parameter polynomial analysis of regression provided by the SAS program package with the calculation of the $\mathrm{ED}_{50}$ via the inflexion point.

\section{Results}

\section{$P P A R \gamma$ visualisation}

An immunostained day 12 lutein cell is shown in Fig. 1. The orange colour of the nucleus compared with the control, omitting the anti-PPAR $\gamma$ antibody and incubating the cells with the second, fluorescent antibody (middle cell in Fig. 1), provided evidence for nuclear PPAR $\gamma$. In contrast, cytoplasmic PPAR $\gamma$ level is low in lutein cells.

\section{$P P A R \gamma m R N A$ and PPAR $\gamma$ isoforms}

Figure 2A demonstrates the presence of PPAR $\gamma$ mRNA in midphase lutein cells. The electropherogram indicates PPAR $\gamma$ cDNA bands produced by reverse transcription PCR from the mRNA of lutein cells. Two primer pairs were used, specifying internal fragments of the PPAR $\gamma$ gene and amplifying 760 and $1200 \mathrm{bp}$. The analysis of $\operatorname{PPAR} \gamma_{1}$ and PPAR $\gamma_{2}$ was performed at the protein level. The isoforms derive from the same gene by alternate post-transcriptional splicing (Tontonoz et al. 1994). To identify the isoforms, the proteins of lutein cell lysates were separated by electrophoresis, blotted and immunochemically stained. The densitometric result is shown by Fig. 2B (lane 2). Lutein cells express $\operatorname{PPAR} \gamma_{1}$ with a relative molecular mass of 52000 and PPAR $\gamma_{2}$ with one of 55 000. The PPAR $\gamma$ forms are phosphorylated as demonstrated by the binding of antibodies to the phosphotyrosine epitope of the proteins (Fig. 2B, lane 3).

\section{PPAR $\mathrm{Y}$ expression predominates in large lutein cells}

The analysis of the PPAR $\gamma$ expression in small and large day 12 lutein cells was performed by flow cytometry. The $\operatorname{PPAR} \gamma$ content of small lutein cells was $39 \pm 6 \%$ of the content of large lutein cells. The analysis of day 5 and day 

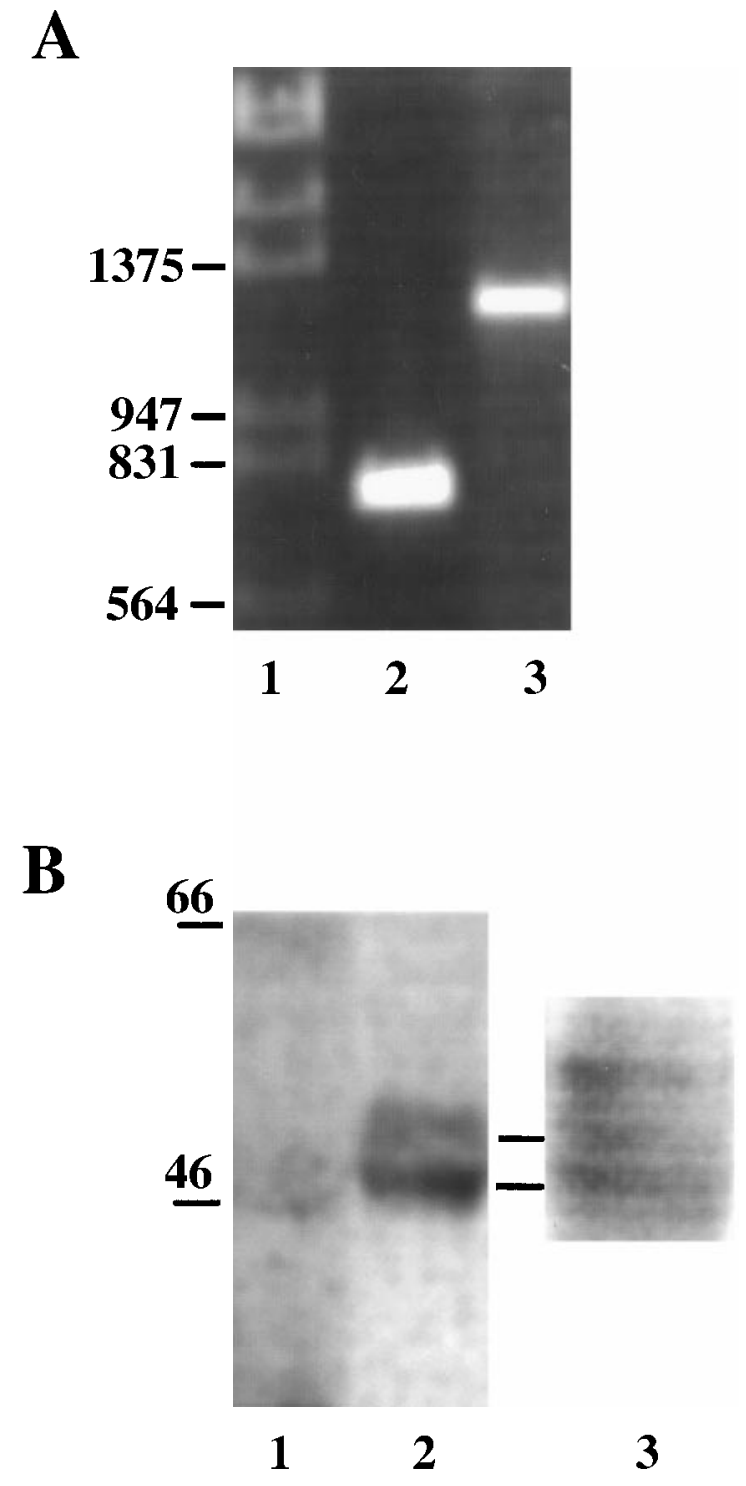

Figure 2 Analysis of PPAR $\gamma$ in midphase lutein cells. (A) Electropherogram of cDNA-PPAR $\gamma$ of midphase lutein cells. Lane 1, molecular mass marker; lane 2, cDNA-PPAR $\gamma, 760 \mathrm{bp}$; lane 3, cDNA-PPAR $\gamma, 1200$ bp. (B) Immunoblot of PPAR $\gamma$. Lane 1, molecular mass 'rainbow' marker and control (incubation without the specific PPAR $\gamma$ antibody); lane 2, PPAR $\gamma$ isoforms with relative molecular masses of 52000 and 55 000. Lane 3 demonstrates the densitometrical detection of phosphotyrosine in PPAR $\gamma$ isoforms separated by PAGE and stained after blotting by antiphosphotyrosine antibody-peroxidase conjugate. In this blot, other phosphorylated proteins are also detected (band above the PPAR $\gamma$ bands).

12 large lutein cells is shown in Fig. 3. Day 5 lutein cells developed higher fluorescence intensity than day 12 cells, indicative of a decrease in the PPAR $\gamma$ expression during luteal phase progress.
Non-adherent granulosa cells from large follicles were fluorescence negative, in contrast to cells of the follicular wall not further characterised in our study.

\section{PPAR $\mathrm{\gamma}$ turnover}

Day 12 lutein cells were incubated with actinomycin D in order to block de novo synthesis of the PPAR $\gamma$ protein. After $24 \mathrm{~h}$, the portion of PPAR $\gamma$-positive cells was compared with the control without actinomycin D treatment. The results are shown in Table 1. The percentage of PPAR $\gamma$-positive cells after exposure to actinomycin D was $75 \%$ of the control value, indicating a low turnover relative to other regulatory proteins.

The small PPAR $\gamma$ protein breakdown may be a function of the cell cycle activity. To examine this hypothesis the cells were incubated with ATA, as we found that lutein cells respond to ATA by increasing the portion of cells with DNA synthesis, measured by flow cytometry and indicated as S-phase cells (Table 2). ATA was more highly effective in triggering PPAR $\gamma$ degradation than actinomycin D and cooperated with actinomycin D in promoting the PPAR $\gamma$ degradation (Table 1), indicative of the role of pathways involved in the cell cycle progression for the breakdown rate of PPAR $\gamma$.

\section{Cell cycle}

Lutein cells from the midphase of the ovarian cycle are fully differentiated and low in the portion exhibiting DNA synthesis (Table 2). ATA promoted the cell cycle activity of lutein cells, demonstrated by a marked increase of the cellular S-phase percentage (Table 2). In this way, the relationship between PPAR $\gamma$ expression and cell cycle progress could be studied. The expression of PPAR $\gamma$ decreased during ATA-induced cell cycle progress (Tables 1 and 2) whereas the endogenous ligand 15-dPGJ selective for PPAR $\gamma$ (Forman et al. 1995) did not affect the cell cycle (Table 2). However, 15-dPGJ 2 dose dependently reversed the ATA-induced progress of the cell cycle (Table 2).

$P P A R \gamma$ ligands promote progesterone secretion from lutein cells

In order to obtain information about the role of PPAR $\gamma$ in steroidogenic activity, the $15-\mathrm{dPGJ}_{2}$ dose response of progesterone release from day 12 lutein cells was studied. First, we tested the cell response to naturally occurring stimulation of the steroidogenic activity in comparison with forskolin-triggered, cAMP-mediated activity (Fig. 4C). The data are indicative of the ability of day 12 lutein cells to respond in vitro to a signal stimulating the progesterone secretion from functionally intact lutein cells. Next, the effect of PPAR $\gamma$ ligands was studied (Fig. 4A and $\mathrm{B})$. The cells responded dose dependently to 


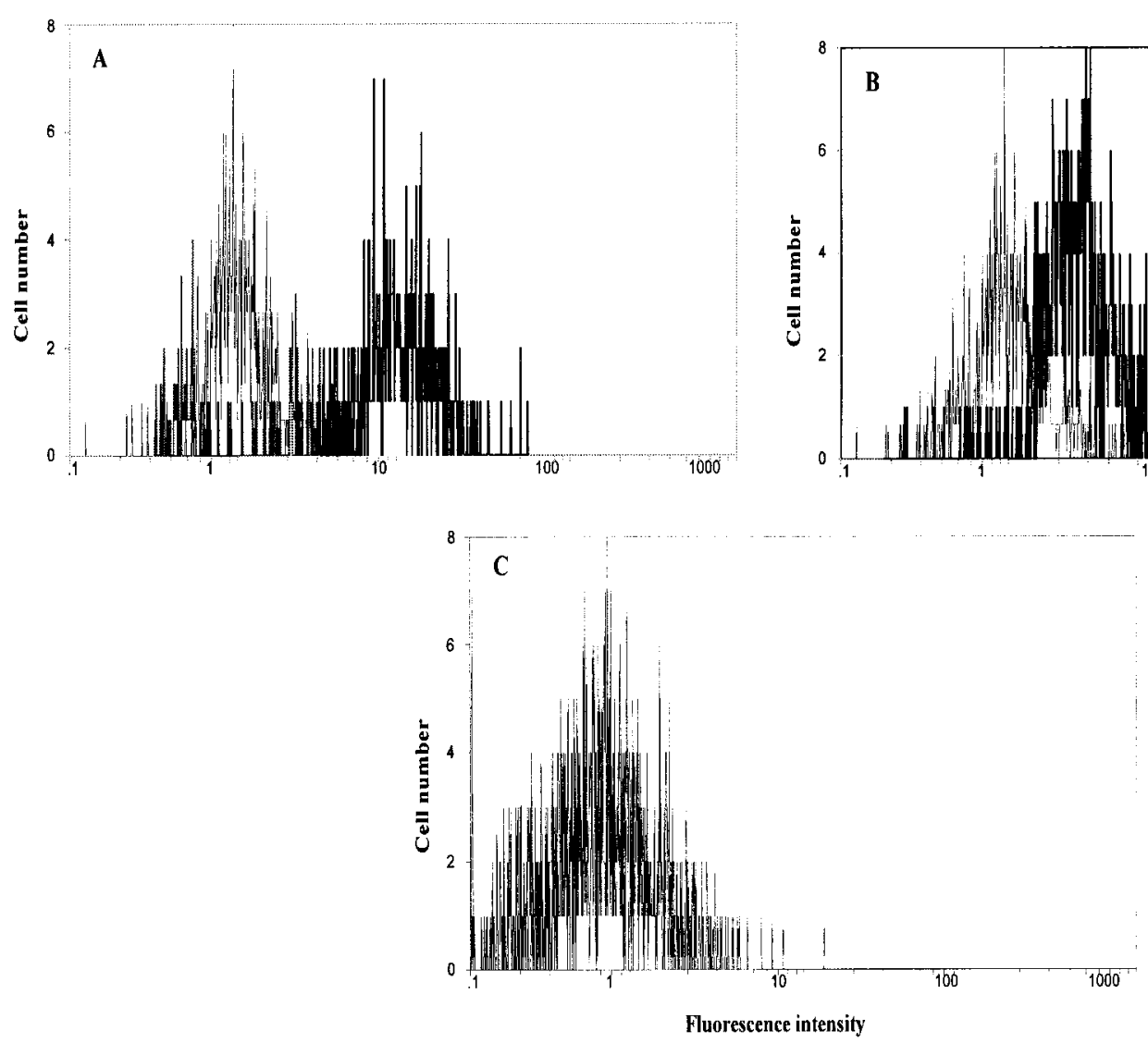

Figure 3 Quantification of PPAR $\gamma$ in lutein and granulosa cells by flow cytometry. Experiments run in triplicate (lutein cells) and duplicate (granulosa cells) with duplicate measurements by flow cytometry. A representative tracing showing (A) day 5, (B) day 12 lutein cells and (C) granulosa cells. The number of fluorescence-positive, large cells (ordinate) and the fluorescence intensity per cell (channel number, abscissa) were plotted (the higher the PPAR $\gamma$ content per cell, the stronger the cellular fluorescence indicated by shifting the channel number toward an increasing number). The thin-line peaks represent controls, the bold-line peaks PPAR $\gamma$-positive cells. The bold-line peak of (A) differed significantly from the corresponding peak of $(B)$ and both peaks from the control $\left(\chi^{2}\right.$ analysis, $\left.P<0 \cdot 05\right)$. Controls were obtained by incubation of an aliquot from the cell suspension without PPAR $\gamma$-specific antibodies and with fluorogenic antibodies. By calibrating the fluorescence intensity with standard beads, the amount of PPAR $\gamma$ per cell was calculated. Large lutein cells gated and analysed by flow cytometry expressed $0 \cdot 6-5$ (day 12 ) and 6-12 (day 5) fmol PPAR $\gamma$ per cell. (C) Granulosa cells aspirated from follicles with a diameter of $5 \pm 1 \mathrm{~mm}$ were immunostained by a technique identical to that in $(\mathrm{A})$. The cells were fluorescence negative as only a thin-line peak is evident, indicating that PPAR $\gamma$ expression is lacking.

$15-\mathrm{dPGJ}_{2}$ by increasing the release of progesterone $(1 \cdot 5$-fold as compared with the control) into the culture medium (Fig. 4A). Then, we compared the action of ATA as a drug exerting a suppressive effect on PPAR $\gamma$ expression to the action of natural and pharmacological ligands. ATA inhibited the progesterone secretion. Only in high dosage $(>400 \mathrm{nM})$ did $15-\mathrm{dPGJ}_{2}$ abrogate the ATA effect on the progesterone secretion (Fig. 4D). A selective $\operatorname{PPAR} \gamma$ ligand, the thiazolidinedione ciglitizone, significantly stimulated the progesterone secretion dose dependently (Fig. 4B) comparable to the prostaglandin (Fig. 4A) or the dose response to human chorionic gonadotrophin (hCG) (Fig. 4B and C) mediated by $\mathrm{LH}$ receptors. As shown by Fig. 4B, the PPAR $\gamma$ ligand did not cooperate with hCG, indicative of a different level of action. In high dosage, however, the ciglitizone was found to be cytotoxic for lutein cells and the progesterone release decreased, indicative of the importance of cell integrity in the maintenance of steroidogenic activity and of a role of $\operatorname{PPAR} \gamma$ in regulating the activity, rather than other pathways which may be involved in mediating the $15-\mathrm{dPGJ}_{2}$ effect.

Finally, the reduction of PPAR $\gamma$ by ATA was used to establish the relationship between PPAR $\gamma$ expression and progesterone secretion (Fig. 4E). By decreasing the PPAR $\gamma$ expression the progesterone secretion decreased (Fig. 4E) since the slope of the regression line was found to be significant $(P<0 \cdot 05$, power of the $t$-test $>0 \cdot 8)$. 
Table 1 Factors affecting percentage of PPAR $\gamma$-positive cells. Day 12 lutein cells were incubated for $24 \mathrm{~h}$ or $48 \mathrm{~h}$ without (control) or with additives. Means and S.D. are shown of three independent experiments with duplicate determinations

\begin{tabular}{|c|c|c|c|}
\hline & & $\operatorname{PPAR} \gamma-$ & cells $(\%)$ \\
\hline & Concentration $(\mu \mathrm{M})$ & $24 \mathrm{~h}$ & $48 \mathrm{~h}$ \\
\hline Treatment & & & \\
\hline Control & - & $85 \pm 5$ & $73 \pm 6$ \\
\hline Actinomycin D & $10 \cdot 0$ & $64 \pm 4$ & ND \\
\hline ATA & $10 \cdot 0$ & $55 \pm 6$ & $40 \pm 5$ \\
\hline ATA $(10 \mu \mathrm{M})+$ actinomycin D & $10 \cdot 0$ & $43 \pm 5$ & ND \\
\hline $15-\mathrm{dPG} \mathrm{j}_{2}$ & $0 \cdot 20$ & $81 \pm 8$ & $75 \pm 4$ \\
\hline & $0 \cdot 49$ & $78 \pm 4$ & $68 \pm 6$ \\
\hline ATA $(10 \mu \mathrm{M})+15-\mathrm{dPGJ}_{2}$ & $0 \cdot 49$ & $70 \pm 5$ & $64 \pm 3$ \\
\hline
\end{tabular}

ANOVA followed by a least significant difference test revealed that differences at least $1 \cdot 76$-fold the mean S.D. of two means were significant $(P<0 \cdot 05)$.

$\mathrm{ND}=$ not determined.

\section{Discussion}

PPAR $\gamma$ is known to be expressed in numerous tissues, albeit at different levels (Wahli et al. 1995, Braissant et al. 1996). More recent studies demonstrated PPAR mRNA in oestrogen-dependent reproductive tissues (Nunez et al. 1997, Sundvold et al. 1997), and provided evidence for the activation of oestrogen-dependent genes by PPARs (Nunez et al. 1997). However, the reports only described the expression of PPAR $\alpha$ (Nunez et al. 1997) and PPAR $\gamma$ (Sundvold et al. 1997) at the mRNA level in ovarian cells. Investigations on PPAR $\gamma$ expression in female reproductive cells at the protein level, enabling functional analysis, are seemingly lacking as yet. This paper reports on the expression of PPAR $\gamma$ in bovine lutein cells at the mRNA and protein levels. Our results show that the PPAR $\gamma$ proteins are active and are involved in the control of progesterone production, a functional differentiation marker of lutein cells. Moreover, the data presented are indicative of another novel role of $\operatorname{PPAR} \gamma$, namely the maintenance of a quiescent cell cycle in large lutein cells.

The underlying molecular mechanisms by which PPAR $\gamma$ brings about these effects are not fully understood. The majority of studies on PPAR $\gamma$ are limited to the adipogenic regulation, as $\operatorname{PPAR} \gamma$ is believed to play a primary role in the storage and catabolism of lipids in adipose tissue (Kliewer et al. 1997). Apart from ligands, such as $15-\mathrm{dPGJ}_{2}$, insulin is thought to regulate the activity of PPAR $\gamma$ via mitogen-activated protein (MAP) kinase-mediated phosphorylation of $\operatorname{PPAR} \gamma(\mathrm{Hu}$ et al. 1996, Zhang et al. 1996b). However, the reports concerning cross-talk between insulin and PPAR $\gamma$ signalling are inconsistent. The conclusions from a study based on transfection techniques were that insulin synergises with a $\operatorname{PPAR} \gamma$ ligand and can activate the receptor in a ligandindependent fashion. The mediator of the insulin effect is MAP kinase, which can phosphorylate PPAR $\gamma$ (Zhang

Table 2 15-dPG) ${ }_{2}$ reverses ATA-induced cell cycle progress. Cell cycle was analysed by flow cytometry. The mean percentage of three independent cell preparations are shown. The coefficients of variation (variation source from three independent experiments with duplicate measurements) were average for $\mathrm{G}_{0} / \mathrm{G}_{1} 4 \%, M+\mathrm{G}_{2} 9 \%$ and $\mathrm{S} 6 \%$

\begin{tabular}{|c|c|c|c|c|}
\hline & \multirow[b]{2}{*}{ Concentration $(\mu \mathrm{M})$} & \multicolumn{3}{|c|}{ Cell cycle phases } \\
\hline & & $\mathrm{G}_{0} / \mathrm{G}_{1}$ & $M+G_{2}$ & $\mathrm{~S}$ \\
\hline \multicolumn{5}{|l|}{ Treatment } \\
\hline Control & - & $87 \cdot 0$ & $3 \cdot 0$ & $10^{\mathrm{a}}$ \\
\hline \multirow{2}{*}{$15-\mathrm{dPGJ})_{2}$} & $0 \cdot 20$ & $86 \cdot 7$ & $3 \cdot 3$ & $10^{\mathrm{a}}$ \\
\hline & $0 \cdot 49$ & $87 \cdot 2$ & $2 \cdot 8$ & $10^{\mathrm{a}}$ \\
\hline \multirow[t]{3}{*}{ ATA } & $5 \cdot 0$ & $86 \cdot 8$ & $2 \cdot 2$ & $11^{\mathrm{a}}$ \\
\hline & $10 \cdot 0$ & $82 \cdot 0$ & $0 \cdot 0$ & $18^{\mathrm{b}}$ \\
\hline & $15 \cdot 0$ & $81 \cdot 0$ & $0 \cdot 0$ & $19^{b}$ \\
\hline ATA $(10 \mu \mathrm{M})+15-\mathrm{dPGJ}_{2}$ & $0 \cdot 20$ & $85 \cdot 0$ & $0 \cdot 0$ & $15^{\mathrm{a}}$ \\
\hline ATA $(10 \mu \mathrm{M})+15-\mathrm{dPG})_{2}$ & $0 \cdot 49$ & $87 \cdot 1$ & $0 \cdot 9$ & $12^{\mathrm{a}}$ \\
\hline
\end{tabular}

Different superscripted letters show significant $(P<0 \cdot 01)$ differences $\left(\chi^{2}\right.$ analysis) between control and treatment group. 

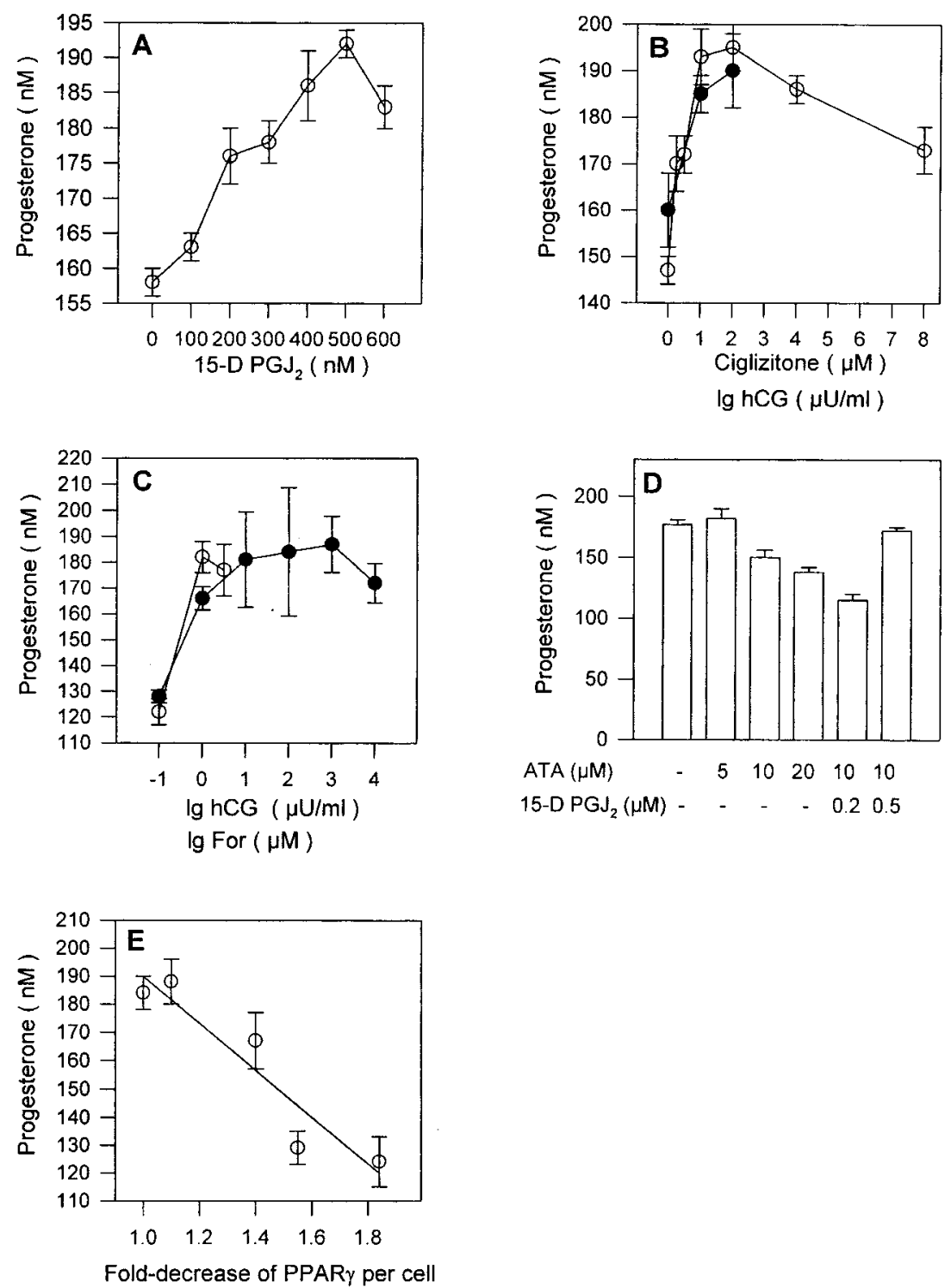

Figure 4 PPAR $\gamma$-mediated regulation of progesterone secretion from lutein cells. (A) Dose response of the progesterone secretion to endogenous ligand. Experiments run in triplicate with quadruplicate determinations. Day 12 lutein cells $\left(10^{6} / \mathrm{ml}\right) \mathrm{were}$ incubated for $24 \mathrm{~h}$ with $15-\mathrm{dPG}_{2}$ at concentrations indicated on the abscissa. The differences between control (obtained by adding the solvent of $15-\mathrm{dPG} \mathrm{J}_{2}$ ) and treatments are significant (ANOVA followed by least-significant difference test, $P<0 \cdot 01$, power of the test $>0 \cdot 8$ ). EC ${ }_{50}$ was $110 \pm 24 \mathrm{nM}$. Circles stand for means, bars for S.E.M. (B) The thiazolidinedione ciglitizone (O), a pharmacological ligand for PPAR $\gamma$, activates progesterone secretion from day 12 lutein cells (incubation for $24 \mathrm{~h}, 10^{6}$ cells $/ \mathrm{ml}$ ). The differences between control and treatments are significant (ANOVA followed by least-significant difference test, $P<0 \cdot 01$, power of the test $>0 \cdot 8$ ). The solvent for ciglitizone was added to the control $(0 \mu \mathrm{M}$ ciglitizone). The drug does not cooperate with hCG $(\mathbf{O})$. Experiments run in triplicate with duplicate determinations. Symbols stand for means, bars for S.E.M. (C) Dose response to the luteotrophic hormone hCG that binds to LH receptors, inducing a cAMP-mediated rise in progesterone secretion. The differences between lowest and higher dose are significant (ANOVA followed by least-significant difference test, $P<0 \cdot 01$, power of the test $>0 \cdot 8)$. Aliquots of the cell suspension $\left(10^{6} / \mathrm{ml}^{\prime}\right)$ were incubated for $24 \mathrm{~h}$ with hCG $(-)$ at the final concentrations indicated on the abscissa. The circles and bars stand for mean and S.D. $\bigcirc$ shows forskolin-induced (For), cAMP-mediated activation of the steroidogenesis. Experiments run in triplicate with duplicate determinations. (D) ATA dose dependently inhibits progesterone release from day 12 lutein cells (incubation for $24 \mathrm{~h}, 10^{6}$ cells $/ \mathrm{ml}$ ). Only the high dose of $15-\mathrm{dPG} \mathrm{J}_{2}$ reverses the ATA effect (ANOVA followed by least-significant difference test, $P<0 \cdot 05$ ). Experiments run in triplicate with duplicate determinations. Bars stand for means, error bars for S.E.M. (E) Relationship between intracellular PPAR $\gamma$ level and progesterone secretion. The cells were incubated for $24 \mathrm{~h}$. The experiments were run in triplicate with duplicate determinations. PPAR $\gamma$ levels were determined by flow cytometry. ATA $(0,5,10,20$ and $30 \mu \mathrm{M})$ was used to decrease the PPAR $\gamma$ level. Circles stand for means, bars for S.E.M. The line represents a significant $(P<0 \cdot 05)$ slope obtained by analysis of regression. 
et al. 1996b). The data from another study, also based on transfection and mutation techniques, provided evidence for the opposite result, namely the inhibition of adipogenesis through MAP kinase-mediated phosphorylation of PPAR $\gamma$ (Hu et al. 1996). Our data concerning the role of PPAR $\gamma$ phosphorylation are preliminary but suggest that PPAR $\gamma$ of midphase lutein cells is phosphorylated. Thereby, PPAR $\gamma$ may mediate the observed effects of its ligands, $15-\mathrm{dPGJ}_{2}$ and ciglitizone, as a phosphorylated molecule.

Midphase lutein cells are believed to contribute to the major part of the circulating progestins while oestrogens disappear from the circulation (Park-Sarge et al. 1995). At luteal midphase the bovine corpus luteum is fully developed (Juengel et al. 1993). Regression of the corpus luteum can be induced by $\mathrm{PGF}_{2 \alpha}$ at this time (Fraser et al. 1995). Intraluteal infusion of some prostaglandins of the $\mathrm{E}$, $\mathrm{I}, \mathrm{A}$, and $\mathrm{D}$ series prevents the $\mathrm{PGF}_{2 \alpha}$ action without affecting the progesterone level (Zelinski-Wootan \& Stouffer 1990).

Our data provide evidence that the natural ligand of $\operatorname{PPAR} \gamma, 15-\mathrm{dPGJ}_{2}$, and a thiazolidinedione, a selective ligand for $\operatorname{PPAR} \gamma$, stimulate the progesterone secretion from lutein cells of the luteal midphase. Moreover, PPAR $\gamma$ is expressed at higher level in day 5 than in day 12 lutein cells. One of the most prominent events during the differentiation of lutein cells from follicular precursors is the increased ability to produce and release progestins. Therefore, PPAR $\gamma$ (and its ligands) appear to be involved in the differentiation of lutein cells. Support for this contention came from our experimental data using ATA as an inducer of the cell cycle progress and as a stimulator of $\operatorname{PPAR} \gamma$ breakdown. The observation that a ligand of $\operatorname{PPAR} \gamma, 15-\mathrm{dPGJ}_{2}$, is able to reverse the ATA effect provided evidence for the role of active PPAR $\gamma$ in the maintenance of a quiescent cell cycle, probably required for lutein cell function. In adipogenic cell systems, PPAR $\gamma$ is downregulated by cytokines, such as tumour necrosis factor- $\alpha$ (TNF $\alpha$ ) produced by activated immunocytes, fibroblasts, and endothelial cells (Zhang et al. 1996a). In analogy to lutein cells, the decrease is accompanied by dedifferentiation (Zhang et al. 1996a). We did not use $\mathrm{TNF} \alpha$, which may occur naturally in response to the interleukin-1 produced by luteinising granulosa cells (Breard et al. 1998), as a tool for the downregulation of $\operatorname{PPAR} \gamma$ in the present study. However, as the PPAR $\gamma$ expression appears to be necessary for the maintenance of a differentiated phenotype even in lutein cells, luteolysis may be mediated by activities acting negatively on PPAR $\gamma$ expression.

Data from other studies on the $15-\mathrm{dPGJ}_{2}-\mathrm{PPAR} \gamma$ system are limited to transfection/cotransfection assays, which indicate that PPAR $\gamma$ chimeras start to respond with reporter production to the PPAR $\gamma$ ligand at a concentration of $100 \mathrm{nM}$ with an $\mathrm{EC}_{50}$ of $2 \mu \mathrm{M}$ (Forman et al. 1995, Kliewer et al. 1995). Interestingly, high doses of
PPAR $\gamma$ ligand tended to decrease (Kliewer et al. 1995) and significantly decreased (Forman et al. 1995) the reporter production. Natural lutein cells respond to the PPAR $\gamma$ ligand with a dose-dependent increase of progesterone secretion, exhibiting an $\mathrm{EC}_{50}$ of about $110 \mathrm{nM}$. The progesterone secretion declines with a high dose (490 $\mathrm{nM}$ ) of $15-\mathrm{dPGJ}_{2}$. A similar dose response was observed using a thiazolidinedione as a specific ligand (Forman et al. 1995) for $\operatorname{PPAR} \gamma$. The gonadotrophin effect on the progesterone secretion was monitored for comparison with a known stimulatory system acting via $\mathrm{LH}$ receptors and cAMP signalling. Gonadotrophin stimulated the progesterone secretion at a level comparable with the PPAR $\gamma$ ligand. The lutein cells again responded to a high dose by decreasing the progesterone secretion. The pathways involved in PPAR $\gamma$-mediated action differ from those involved in LH receptor-cAMP-mediated stimulation, since the ligands of PPAR $\gamma$ and of $\mathrm{LH}$ receptors failed to exhibit antagonistic or cooperative activities. This result is consistent with a report indicating that $15-\mathrm{dPGJ}_{2}$ does not mediate its message to PPAR $\gamma$ through $\mathrm{Ca}^{2+}$-signalling triggered by stimulation of plasma membrane receptors (Kliewer et al. 1994). The regulatory role of PPAR $\gamma$ for the steroidogenic activity may result from the ability of PPARs to activate genes which encode enzymes of the cholesterol biosynthetic pathway, including one of the rate-limiting enzymes, the 3-hydroxy-3-methyl-glutaryl coenzyme A synthase (Rodriguez et al. 1994), which also seems to be controlled by SREBPs, the other group of transcription factors also involved in cholesterol metabolism and in the activation of genes that encode enzymes of fatty acid metabolism (Brown \& Goldstein 1997). SREBPs-PPAR $\gamma$ cross-talk seems to occur in adipocytes as SREBP-mediated transcription may augment the PPAR $\gamma$-mediated transcription (Kim \& Spiegelman 1996). However, studies on transgenic mice provided evidence for SREBP action predominantly in liver cells (Shimano et al. 1996), which have a markedly higher expression of PPAR $\alpha$ than PPAR $\gamma$. Studies on female reproductive cells are apparently lacking.

In summary, our results provide evidence for a relationship between PPAR $\gamma$ and progesterone production, a function typical of differentiated lutein cells, and for the inhibition of drug-induced cell cycle progress by a PPAR $\gamma$ ligand, suggesting that PPAR $\gamma$ appears to coordinate the activity of genes involved in cell cycle progress and in executing the differentiation programme of lutein cells.

\section{References}

Braissant O, Foufelle F, Scotto C, Dauca M \& Wahli W 1996 Differential expression of peroxisome proliferator-activated receptors (PPARs): tissue distribution of $\operatorname{PPAR} \alpha, \beta$, and $\gamma$ in the adult rat. Endocrinology 137 354-366.

Breard E, Delarue B, Benhaim A, Feral C \& Leymarie P 1998 Inhibition by gonadotrophins of interleukin-1 production by rabbit 
granulosa and theca cells: effects on gonadotrophin-induced progesterone production. European Journal of Endocrinology 138 328-336.

Brown MS \& Goldstein JL 1997 The SREBP pathway: regulation of cholesterol metabolism by proteolysis of a membrane-bound transcription factor. Cell 89 331-340.

Chen F, Law SW \& O'Malley BW 1993 Identification of two mPPAR related receptors and evidence for the existence of five subfamily members. Biochemical and Biophysical Research Communications 196 671-677.

Dennis EA 1994 Diversity of group types, regulation, and function of phospholipase $\mathrm{A}_{2}$. Journal of Biological Chemistry 269 13057-13060.

Doody KJ, Lorence MC, Mason JI \& Simpson ER 1990 Expression of messenger ribonucleic acid species encoding steroidogenic enzymes in human follicles and corpora lutea throughout the menstrual cycle. Journal of Clinical Endocrinology and Metabolism 70 10411045.

Fields MJ, Barros CM, Watkins WB \& Fields PR 1992 Characterization of large luteal cells and their secretory granules throughout the estrous cycle of the cow. Biology of Reproduction 46 535-545.

Forman BM, Tontonoz P, Chen J, Brun R, Spiegelman BM \& Evans RM 1995 15-Deoxy- $\Delta^{12,14}$-prostaglandin $\mathrm{J}_{2}$ is a ligand for the adipocyte determination factor PPAR $\gamma$. Cell 83 803-812.

Fraser HM, Lunn SF, Cowen GN \& Illingworth PJ 1995 Induced luteal regression in the primate. Evidence for apoptosis and changes in c-myc protein. Journal of Endocrinology 144 131-137.

Fukushima M 1992 Biological activities and mechanisms of action of $\mathrm{PGJ}_{2}$ and related compounds: an update. Prostaglandins, Leukotrienes and Essential Fatty Acids 47 1-12.

Goldring NB, Farkash T, Goldschmit T \& Orly J 1986 Immunofluorescent probing of the mitochondrial cholesterol side-chain cleavage cytochrome P-450 expressed in differentiating granulosa cells in culture. Endocrinology 119 2821-2832.

Gulick T, Cresci S, Caira T, Moore DD \& Kelly DP 1994 The peroxisome proliferator-activated receptor regulates mitochondrial fatty acid oxidative enzyme gene expression. Proceedings of the National Academy of Sciences of the USA 91 11012-11016.

Hu E, Kim JB, Sarraf P \& Spiegelman BM 1996 Inhibition of adipogenesis through MAP kinase-mediated phosphorylation of PPAR $\gamma$. Science 274 2100-2103.

Issemann I \& Green S 1990 Activation of a member of the steroid hormone receptor superfamily by peroxisome proliferators. Nature 347 645-650.

Juengel JL, Garverick HA, Johnson AL, Youngquist RS \& Smith MF 1993 Apoptosis during luteal regression in cattle. Endocrinology 132 249-255.

Keller H, Dreyer C, Medin J, Mahfoudi A, Ozato K \& Wahli W 1993 Fatty acids and retinoids control lipid metabolism through activation of peroxisome proliferator-activated receptor retinoid X receptor heterodimers. Proceedings of the National Academy of Sciences of the USA 90 2160-2164.

Kim JB \& Spiegelman BM 1996 ADD1/SREBP1 promotes adipocyte differentiation and gene expression linked to fatty acid metabolism. Genes and Development 10 1096-1107.

Kliewer SA, Forman BM, Blumberg B, Ong ES, Borgmeyer Y, Mangelsdorf DJ, Umesono K \& Evans RM 1994 Differential expression and activation of a family of murine peroxisome proliferator-activated receptors. Proceedings of the National Academy of Sciences of the USA 91 7355-7359.

Kliewer SA, Lenhard JM, Willson T, Patel J, Morris DC \& Lehmann JM 1995 A prostaglandin $\mathrm{J}_{2}$ metabolite binds peroxisome proliferator-activated receptor $\gamma$ and promotes adipocyte differentiation. Cell 83 813-819.

Kliewer SA, Sundseth SS, Jones SA, Brown PJ, Wisely GB, Koble CS, Devchand P, Wahli W, Willson TM, Lenhard JM \& Lehmann JM
1997 Fatty acids and eicosanoids regulate gene expression through direct interactions with peroxisome proliferator-activated receptors $\alpha$ and $\gamma$. Proceedings of the National Academy of Sciences of the USA 94 4318-4323.

Löhrke B, Krüger B \& Viergutz T 1993 The glycosylation as source of the variability in prolactin patterns of individual human amniotic fluids. Biological Chemistry Hoppe-Seyler 374 271-279.

Löhrke B, Derno M, Krüger B, Viergutz T, Matthes HD \& Jentsch W 1997 Expression of sulphonylurea receptors in bovine monocytes from animals with a different metabolic rate. Pflïgers Archiv 434 $712-720$

Monniaux D, Pisselet C \& Fontaine J 1994 Uncoupling between proliferation and differentiation of ovine granulosa cells in vitro. Journal of Endocrinology 142 497-510.

Nunez S, Medin JA, Braissant O, Kemp L, Wahli W, Ozato K \& Segars JH 1997 Retinoid X receptor and peroxisome proliferatoractivated receptor activate an estrogen responsive gene independent of the estrogen receptor. Molecular and Cellular Endocrinology 127 27-40.

Park-Sarge OK, Parmer TG, Gu Y \& Gibori G 1995 Does the rat corpus luteum express the progesterone receptor gene? Endocrinology 136 1537-1543.

Rodriguez JC, Gil-Gomez G, Hegardt FG \& Haro D 1994 The peroxisome proliferator-activated receptor mediates the induction of the mitochondrial 3-hydroxy-3-methyl glutaryl-CoA synthase gene by fatty acids. Journal of Biological Chemistry 269 18767-18772.

Sawada M \& Carlson JC 1991 Rapid plasma membrane changes in superoxide radical formation, fluidity, and phospholipase $A_{2}$ activity in the corpus luteum of the rat during induction of luteolysis. Endocrinology 128 2992-2998.

Schmidt A, Endo N, Rutlage SJ, Vogel R, Shinar D \& Rodan GA 1992 Identification of a new member of the steroid hormone receptor superfamily that is activated by a peroxisome proliferator and fatty acids. Molecular Endocrinology 6 1634-1641.

Schoonjans K, Watanabe M, Suzuki H, Mahfoudi A, Krey G, Wahli W, Grimaldi P, Staels B, Yamamoto T \& Auwerx J 1995 Induction of the acyl-coenzyme A synthetase gene by fibrates and fatty acids is mediated by a peroxisome proliferator response element in the C promoter. Journal of Biological Chemistry 33 19269-19276.

Shimano H, Horton JD, Hammer RE, Shimomura I, Brown MS \& Goldstein JL 1996 Overproduction of cholesterol and fatty acids causes massive liver enlargement in transgenic mice expressing truncated SREBP-1a. Journal of Clinical Investigations 98 15751584.

Stöhr M, Vogt-Schaden M, Knobloch M \& Vogel R 1978 Evaluation of eight fluorochrome combinations for simultaneous DNA-protein flow analysis. Stain Technology 53 205-215.

Sundvold H, Brzozowska A \& Lien S 1997 Characterization of bovine peroxisome proliferator-activated receptors $\gamma 1$ and $\gamma 2$ : genetic mapping and differential expression of the two isoforms. Biochemical and Biophysical Research Communications 239 857-861.

Tiemann U, Löhrke B, Köwitz J \& Alm H 1993 Effect of prolactin isolated from human amniotic fluid on cultured bovine cells of the reproductive tract and splenocytes. Reproduction in Domestic Animals 28 272-278.

Tontonoz P, Hu E \& Spiegelman BM 1994 Stimulation of adipogenesis in fibroblasts by PPAR $\gamma_{2}$, a lipid activated transcription factor. Cell 79 1147-1156.

Wahli W, Braissant O \& Desvergne B 1995 Peroxisome proliferator activated receptors: transcriptional regulators of adipogenesis, lipid metabolism and more. Chemistry and Biology 2 261-266.

Zelinski-Wooten MB \& Stouffer RL 1990 Intraluteal infusion of prostaglandins of the E, D, I, and A series prevents PGF2 $\alpha$ induced, but not spontaneous, luteal regression in rhesus monkeys. Biology of Reproduction 43 507-516. 
Zhang B, Berger J, Hu E, Szalkowski D, White-Carrington S, Spiegelman BM \& Moller DE 1996 a Negative regulation of peroxisome proliferator-activated receptor-gamma gene expression contributes to the antiadipogenic effects of tumor necrosis factor-alpha. Molecular Endocrinology 10 1457-1466.

Zhang B, Berger J, Zhou G, Elbrecht A, Biswas S, White-Carrington S, Szalkowski D \& Moller DE 1996 b Insulin- and mitogenactivated protein kinase-mediated phosphorylation and activation of peroxisome proliferator-activated receptor $\gamma$. Journal of Biological Chemistry 271 31771-31774.
Zhu Y, Alvares K, Huang Q, Rao MS \& Reddy JK 1993 Cloning of a new member of the peroxisome proliferator-activated receptor gene family from mouse liver. Journal of Biological Chemistry 268 $26817-26820$.

Received 31 March 1998

Revised manuscript received 22 May 1998

Accepted 21 July 1998 